\title{
Ocena kliniczna wpływu bewacyzumabu w kroplach na morfologię i funkcję pęcherzyka filtracyjnego z objawami niewydolności
}

\author{
Clinical evaluation of the effect of topical bevacizumab on morphology and function of filtering \\ bleb with failure symptoms
}

\author{
Anna Kuna, Tomasz Żarnowski \\ Klinika Diagnostyki i Mikrochirurgii Jaskry, \\ Uniwersytet Medyczny w Lublinie
}

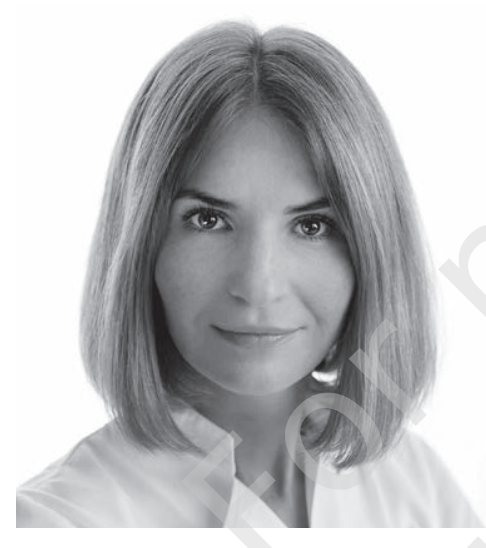

\section{N A JWA ŻN IE JSZE}

Bewacyzumab stanowi skuteczną i bezpieczną terapię pomocniczą dla miejscowych glikokortykosteroidów w celu leczenia wczesnej pooperacyjnej niewydolności pęcherzyka poprzez zmniejszenie unaczynienia na jego powierzchni.

\section{H I G H L I GHTS}

Bevacizumab is an effective and safe adjunctive therapy with topical steroids for the treatment of early postoperative filtering bleb failure as it reduces innervation on the bleb surface.

\section{STRESZCZENIE}

Cel pracy: Ocena przydatności bewacyzumabu w kroplach u pacjentów poddanych trabekulektomii w celu zahamowania gojenia rany pooperacyjnej.

Material i metody: 53 osoby po zabiegu przeciwjaskrowym z wytworzeniem pęcherzyka filtracyjnego, u których doszło do wczesnej, pooperacyjnej niewydolności pęcherzyka kwalifikującej się do zastosowania bewacyzumabu w kroplach. Pełnej analizie statystycznej poddano 30 pacjentów, którzy poza badaniem ciśnienia wewnątrzgałkowego, badaniem w lampie szczelinowej i oceną pęcherzyka w skali MBGS, dodatkowo wykonane mieli zdjęcia fotograficzne pęcherzyka, na podstawie których dokonano pełnej analizy morfologicznej pęcherzyka.

Wyniki: Całkowity sukces po 6 miesiącach, bez stosowania leków przeciwjaskrowych (ciśnienie wewnątrzgałkowe końcowe $<18$ mmHg i obniżenie ciśnienia wewnątrzgałkowego wyjściowego o 30\%) osiągnięto u 18 pacjentów (60\%). Częściowy sukces (obniżenie ciśnienia wewnątrzgałkowego wyjściowego o $30 \%)$ osiągnięto u 19 pacjentów (63,3\%).

Wnioski: Bewacyzumab to skuteczna i bezpieczna terapia pomocnicza dla miejscowych glikokortykosteroidów w leczeniu wczesnej pooperacyjnej niewydolności pęcherzyka poprzez zmniejszenie unaczynienia na jego powierzchni. Ocena średniej powierzchni naczyń pęcherzyka na zdjęciu fotograficznym, dokonana przy użyciu programu ImageJ, koreluje z oceną pęcherzyka w skali MBGS.

Słowa kluczowe: pęcherzyk filtracyjny, powierzchnia naczyń, niewydolność pęcherzyka filtracyjnego 


\section{ABSTRACT}

Objectives: Evaluation of bevacizumab drops in patients undergoing trabeculectomy in order to inhibit postoperative wound healing.

Material and methods: A total of 53 patients treated surgically for glaucoma. The anti-glaucoma procedures with the creation of a filtering bleb were performed. The patients developed early postoperative bleb insufficiency qualifying them for the use of bevacizumab drops. Thirty were completely statistically analyzed; intraocular pressure and slit lamp examinations were performed and the bleb was assessed according to the MBGS. Additionally, photographs of the filtering blebs were made, which were used for bleb morphological analysis.

Results: Total success, after 6 months, without using anti-glaucoma drugs (intraocular pressure $<18 \mathrm{mmHg}$ and a decrease in baseline intraocular pressure by $30 \%$ ) was observed in 18 patients (60\%). Partial success, after 6 months, without using anti-glaucoma drugs (decrease in baseline intraocular pressure by 30\%) was achieved in 19 patients (63.3\%).

Conclusions: Bevacizumab is an effective and safe adjunctive therapy with topical steroids for the treatment of early postoperative filtering bleb insufficiency as it reduces innervation on the bleb surface. Evaluation of the mean surface of bleb vessels on photographs, using ImageJ (Wayne Rasband), correlates with MBGS evaluation of filtering blebs.

Key words: filtering bleb, vessel area, filtering bleb failure

\section{WSTĘP}

Trabekulektomia jest złotym standardem w chirurgii jaskry i powszechnie stosowaną metodą leczenia zabiegowego od czasu jej wprowadzenia w 1968 r. przez Cairnsa [1]. Trabekulektomia jest operacją przeciwjaskrową, której efektem ma być obniżenie ciśnienia wewnątrzgałkowego (CWG) poprzez wytworzenie komunikacji pomiędzy komorą przednią oka a przestrzenią podspojówkową. Celem zabiegów filtracyjnych $\mathrm{w}$ jaskrze jest wytworzenie i utrzymanie na czas nieokreślony przetoki pomiędzy dwiema anatomicznymi przestrzeniami, które fizjologicznie nie są połączone. Sukcesem jest prawidłowo funkcjonujący pęcherzyk filtracyjny. Istnieje wiele czynników mających wpływ na jego funkcję: fibroblasty i ich proliferacja, elementy łączące tkanki wpływające na włóknienie podspojówkowe, cytokiny, ciecz wodnista i naczynia krwionośne. Czynnikami ryzyka predysponującymi do zaburzeń pęcherzyka są: jaskra neowaskularna, rasa czarna, wcześniejszy nieudany zabieg filtracyjny, zapalenie błony naczyniowej, bezsoczewkowość, stan po operacji zaćmy i młody wiek pacjenta. Biorąc pod uwagę czynniki ryzyka i ewentualne niepowodzenie zabiegu u danego pacjenta, chirurg powinien rozważyć inne, alternatywne formy interwencji, takie jak zastosowanie środków powodujących zahamowanie fibroblastów. Ta metoda hamująca proces gojenia się rany znalazła szerokie zastosowanie w celu poprawy skuteczności trabekulektomii. Najczęściej używane antymetabolity to 5-fluorouracyl (5-FU, 5-fluorouracil) oraz mitomycyna C (MMC). Wśród leków antyangiogennych (anty-VEGF, anti-vascular endothelial growth factor) najczęściej stosowany jest bewacyzumab.

Bewacyzumab jest substancją czynną, która jest humanizowanym przeciwciałem monoklonalnym. Wybiórczo łączy się on z białkiem nazywanym ludzkim czynnikiem wzrostu śródbłonka naczyń (VEGF, vascular endothelial growth factor), które wyściela naczynia krwionośne i limfatyczne w organizmie. VEGF to główna cytokina zapoczątkowująca angiogenezę odkryta przez Dvoraka w 1983 r., pierwotnie nazywana czynnikiem przepuszczalności naczyń $[2,3]$. Prawidłowa angiogeneza to proces tworzenia nowych naczyń na bazie już istniejących. Bewacyzumab jest lekiem nowej klasy otrzymywanym drogą inżynierii genetycznej, blokującym angiogenezę dzięki zastosowaniu najnowszych technik immunologicznych. Bewacyzumab jest produkowany w komórkach jajnika chomika chińskiego (CHO, Chinese hamster ovary) oraz zbudowany z ludzkiej immunoglobuliny IgG1 w 93\% i z mysiego fragmentu w 7\%. Wszystkie izoformy VEGF-A są rozpoznawane przez swoistą domenę przeciwciała [4, 5]. Dochodzi do utworzenia kompleksu bewacyzumab - VEGF-A, który blokuje receptory, głównie VEGFR-2, i uniemożliwia aktywację szlaków wewnątrzkomórkowego przetwarzania sygnałów prowadzących do wzrostu proliferacji komórek śródbłonka i wzrostu przepuszczalności naczyń krwionośnych. 
Znane jest zastosowanie $0,1 \mathrm{ml}$ bewacyzumabu (25 mg/ml) w formie iniekcji podspojówkowych w następujący sposób: przed wykonaniem trabekulektomii, bezpośrednio po operacji, dobę po operacji oraz $7 \mathrm{dni}$ po operacji, w celu wspomagania trabekulektomii. Po rocznej obserwacji wykazano podobny efekt operacji po zastosowaniu bewacyzumabu i 5-FU [6].

W naszej klinice przeprowadzono badanie na 21 oczach u 20 pacjentów, u których średnio przez 21 dni zastosowano krople bewacyzumabu z powodu wczesnej pooperacyjnej niewydolności pęcherzyka filtracyjnego. Wykazano istotne zmniejszenie unaczynienia pęcherzyka po 6-miesięcznej obserwacji w 16 przypadkach, w pięciu natomiast pęcherzyk pozostał płaski i niewydolny, wymagający kolejnych interwencji chirurgicznych [7]. W przypadku niewydolności pęcherzyka filtracyjnego standardowe postępowanie pooperacyjne jest zwykle niewystarczające, dlatego podjęto próbę pooperacyjnego stosowania bewacyzumabu.

W niniejszej pracy zostały poddane ocenie skuteczność i bezpieczeństwo stosowania bewacyzumabu w kroplach na morfologię i funkcję pęcherzyka filtracyjnego z objawami niewydolności.

\section{MATERIAŁ BADANIA}

Po uzyskaniu dla projektu pozytywnej opinii Komisji Bioetycznej przy Uniwersytecie Medycznym w Lublinie rozpoczęto kwalifikację pacjentów do grupy badawczej. Badaniem objęto 53 osoby leczone operacyjnie z powodu jaskry, u których stwierdzono wczesną pooperacyjną niewydolność pęcherzyka filtracyjnego. Ogólna liczba niepowodzeń operacji przeciwjaskrowych wykonanych w Klinice Okulistyki w latach 2010-2011 wynosi 53, co stanowi $13,3 \%$ wszystkich operacji przeciwjaskrowych przeprowadzonych w tym okresie.

Kryteria włączania chorych do badania stanowiły: rozpoznana jaskra; wykonany zabieg przeciwjaskrowy z wytworzeniem pęcherzyka filtracyjnego; wczesna, pooperacyjna niewydolność pęcherzyka filtracyjnego, tzn. przekrwienie pęcherzyka, kwalifikujące się do zastosowania bewacyzumabu w kroplach.

Krople bewacyzumabu były przygotowywane według stałej receptury: $5 \mathrm{mg} / \mathrm{ml}$ koncentrat do sporządzania roztworu do infuzji - wlew dożylny, dawka $25 \mathrm{mg} / \mathrm{ml}$, 1 fiolka $4 \mathrm{ml}$, rozcieńczony w stosunku $1: 4 \mathrm{z}$ solą fizjologiczną, stężenie kropli $5 \mathrm{mg} / \mathrm{ml}$, podany w sterylnej buteleczce z kroplomierzem zakupionej przez pacjenta $\mathrm{w}$ aptece, $\mathrm{z}$ zaleceniem przechowywania kropli $\mathrm{w}$ lodówce. Pacjenci stosowali krople bewacyzumabu 5 razy dziennie przez okres indywidualnie ustalony z lekarzem. Byli oni poddani standaryzowanemu badaniu okulistycznemu w momencie włączenia do grupy bada- nej oraz w okresie 2 tygodni, 2 i 6 miesięcy od tego czasu. U każdego z nich przeprowadzone zostało badanie CWG za pomocą tonometru aplanacyjnego Goldmana oraz badanie oczu w lampie szczelinowej ze szczegółową oceną pęcherzyka filtracyjnego w skali Moorfields Bleb Grading System (MBGS).

Pełna grupa badana liczyła 53 osoby, ostatecznej analizie statystycznej poddano 30 pacjentów (12 kobiet, 18 mężczyzn), którzy przeszli pełne badanie kliniczne oraz ich pęcherzyki filtracyjne zostały poddane pełnej analizie morfologicznej (tab. 1).

\section{POWIKŁANIA POOPERACYJNE}

U czterech osób (13,3\%) obserwowano wyciek z pęcherzyka trwający 3 tygodnie. U dwóch pacjentów ustąpił on samoistnie, a pozostałych dwóch trzeba było założyć dodatkowe szwy na spojówkę, z czego u jednej z tych osób zakończyło się to rewizją pęcherzyka filtracyjnego po 6 miesiącach. U jednej osoby doszło do krwotocznego uniesienia naczyniówki, zatem w 3 tygodnie po zabiegu przeprowadzono u niej drenaż naczyniówki z dobrym efektem. U jednego pacjenta miesiąc po zabiegu wystąpiło wypadnięcie tęczówki. Odprowadzono go operacyjnie z podaniem miostatu. Efekt operacji był zadowalający.

\section{ZDJĘCIE FOTOGRAFICZNE PĘCHERZYKA}

U 30 pacjentów biorących udział w badaniu dodatkowo były wykonywane zdjęcia fotograficzne oka po operacji przeciwjaskrowej uwidoczniające pęcherzyk filtracyjny. Zdjęcia zrobiono w 10-krotnym powiększeniu w ciemni fotograficznej, w lampie szczelinowej, na której zainstalowano aparat fotograficzny Nikon FS-2. Zdjęcia były wykonywane w momencie kwalifikacji pacjenta do grupy badawczej, a także po 2 tygodniach, 2 i 6 miesiącach od momentu rozpoczęcia badania. Po ustaleniu jednolitej metody obróbki zdjęć wyznaczono punkty odniesienia, tj. kąciki oka, aby zdjęcia wszystkich pacjentów miały podobną wielkość (ryc. 1A). Wyodrębniono obszar pomiaru naczyń (ROI, Region of interest) stały dla każdego zdjęcia, kształtem przypominający fasolkę (ryc. 1B). Zasadą ustawienia szkicu ROI na zdjęciu było objęcie głębokiego płatka twardówki. Wykorzystując program Photoshop (wersja CS2), tworzono pliki dla każdego pacjenta. Zdjęcia z kolejnych dat nakładano na siebie warstwowo tak, aby pomiar był jak najbardziej obiektywny. Stosowano skalowanie: zmniejszanie, powiększanie lub obracanie, niektóre zdjęcia wymagały korekty kolorystycznej. Za pomocą tabletu graficznego Wacom ręcznie rysowano naczynia na osobnej warstwie w danym pliku, która posłużyła do stworzenia maski (ryc. 1C). Maską określono obszar występowania naczyń w ROI. Utworzone maski zapisywano jako monochromatyczne (czarno-białe) obrazy w formacie TIFF (ryc. 1D). 


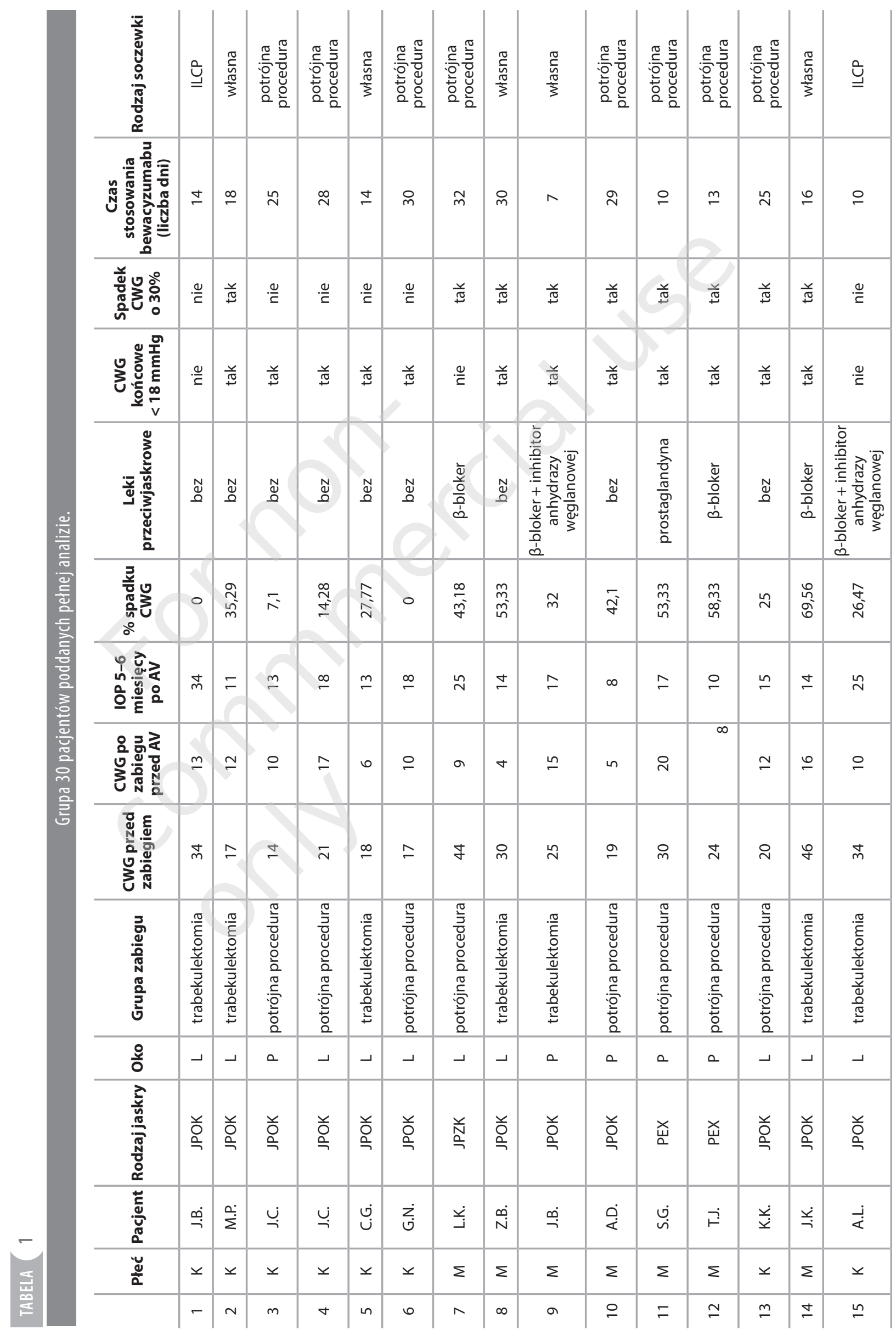




\begin{tabular}{|c|c|c|c|c|c|c|c|c|c|c|c|c|c|c|}
\hline 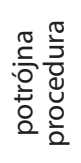 & 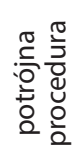 & $\begin{array}{l}\frac{\pi}{5} \\
\bar{n} \\
\frac{\pi}{3}\end{array}$ & $\stackrel{\text { U }}{=}$ & $\begin{array}{l}\frac{\pi}{5} \\
\frac{\tilde{n}}{3} \\
\frac{\pi}{3}\end{array}$ & $\begin{array}{l}\frac{\pi}{\tilde{n}} \\
\frac{\pi}{3}\end{array}$ & $\begin{array}{l}\frac{\pi}{5} \\
\bar{n} \\
\frac{\pi}{3}\end{array}$ & 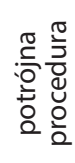 & $\begin{array}{l}\frac{\pi}{0} \\
\frac{\tilde{n}}{\frac{\pi}{3}}\end{array}$ & $\stackrel{\text { U }}{=}$ & \begin{tabular}{l} 
Õ \\
\multicolumn{5}{|c}{} \\
$\frac{\pi}{3}$
\end{tabular} & $\begin{array}{l}\frac{\pi}{\bar{n}} \\
\frac{\pi}{3}\end{array}$ & 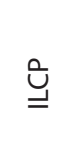 & 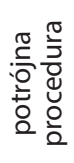 & $\begin{array}{l}\frac{\pi}{\tilde{n}} \\
\frac{\pi}{3}\end{array}$ \\
\hline$\hat{\lambda}$ & $\stackrel{m}{-}$ & $\stackrel{\sigma}{-}$ & $\bar{m}$ & $\Xi$ & $\stackrel{\infty}{\stackrel{\infty}{n}}$ & \pm & ঃ & 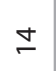 & શి & શิ & $\grave{\lambda}$ & $\stackrel{\sim}{\sim}$ & $\stackrel{\infty}{\sim}$ & $=$ \\
\hline$\stackrel{\mathscr{\nu}}{\underline{\tau}}$ & 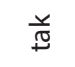 & $\stackrel{\mathscr{O}}{\Gamma}$ & 肎 & 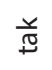 & 总 & 壬 & 总 & 冚 & 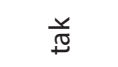 & 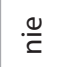 & 离 & 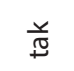 & $\stackrel{\frac{\omega}{\tau}}{\underline{x}}$ & 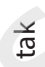 \\
\hline 屵 & 壬 & 莺 & 肎 & 冚 & 壬 & 壬 & 莺 & 营 & 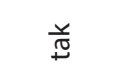 & 壬 & 肎 & 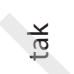 & $\stackrel{\underline{\underline{c}}}{\underline{\tau}}$ &.$\stackrel{\mathscr{U}}{I}$ \\
\hline 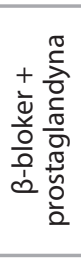 & ه్ & هి & هั & ปี & 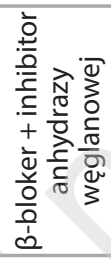 & ฮి & 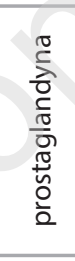 & ปั & 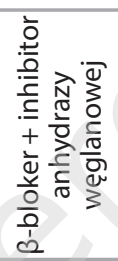 & $\begin{array}{l}\frac{\bar{d}}{\bar{d}} \\
\frac{0}{0} \\
\frac{b}{b}\end{array}$ & ปั & 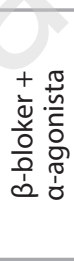 & $\stackrel{\mathbb{N}}{\text { ปิ }}$ & $\stackrel{\mathbb{N}}{\Omega}$ \\
\hline$\stackrel{\infty}{\sim}$ & $\frac{\Delta}{i}$ & $\frac{0}{\stackrel{2}{2}}$ & $\begin{array}{l}\widehat{\infty} \\
\infty \\
\infty \\
\infty\end{array}$ & $\stackrel{\infty}{n}$ & 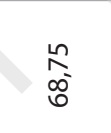 & $\stackrel{\sim}{\stackrel{\sim}{\infty}} \underset{\sim}{\infty}$ & $\frac{m}{\sigma}$ & $\underset{m}{m} \stackrel{m}{m}$ & & 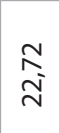 & 犬ิ & $\begin{array}{l}\hat{n} \\
\text { on } \\
\infty\end{array}$ & $\stackrel{\sim}{\underset{I}{\simeq}}$ & $\stackrel{9}{-}$ \\
\hline$\stackrel{\infty}{\sim}$ & $\simeq$ & 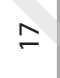 & 으 & $=$ & & $\stackrel{J}{ }$ & $\simeq$ & $\simeq$ & $\stackrel{\circ}{\sim}$ & $\approx$ & $\simeq$ & $a$ & $\stackrel{\infty}{\sim}$ & \pm \\
\hline$\stackrel{\circ}{\sim}$ & $\underset{N}{ }$ & $\stackrel{\mathscr{N}}{\sim}$ & $\stackrel{\infty}{\sim}$ & $\sigma$ & $\stackrel{\circ}{N}$ & $\infty$ & in & $\Xi$ & in & $\approx$ & 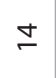 & $=$ & $\stackrel{\circ}{\sim}$ & 으 \\
\hline$\stackrel{\Perp}{\sim}$ & $\stackrel{\infty}{\sim}$ & d & $\widetilde{6}$ & $\mathcal{F}$ & $\tilde{m}$ & ఫ & $\ddot{\sim}$ & $\stackrel{\infty}{-}$ & $\stackrel{\sim}{m}$ & $\approx$ & $\stackrel{+}{m}$ & $\mathcal{F}$ & $\tilde{m}$ & ก \\
\hline 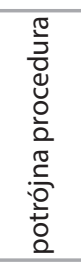 & 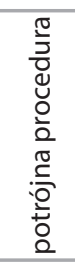 & 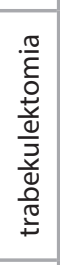 & 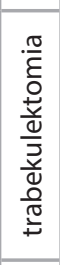 & 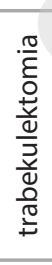 & 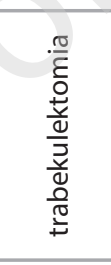 & 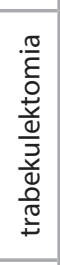 & 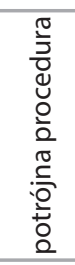 & 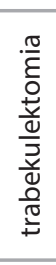 & 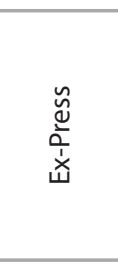 & 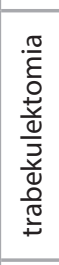 & 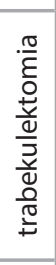 & 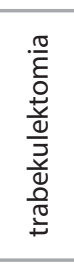 & 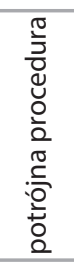 & 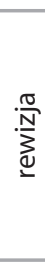 \\
\hline$\lrcorner$ & a & $a$ & a & $a$ & a & $a$ & a & a & a & $a$ & \lrcorner & $a$ & \lrcorner & a \\
\hline $\begin{array}{l}\text { 흑 } \\
\text { 은 }\end{array}$ & $\begin{array}{l}\text { 흠 } \\
\text { 은 }\end{array}$ & $\begin{array}{l}\text { 힌 } \\
\text { 인 }\end{array}$ & 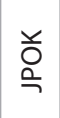 & $\begin{array}{l}\text { 흠 } \\
\text { 은 }\end{array}$ & $\begin{array}{l}\text { 흑 } \\
\text { 인 }\end{array}$ & $\begin{array}{l}\text { 응 } \\
\text { 윽 }\end{array}$ & $\begin{array}{l}\text { 흥 } \\
\text { 은 }\end{array}$ & 흥 & 产 & $\begin{array}{l}\text { 흔 } \\
\text { 은 }\end{array}$ & 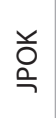 & $\begin{array}{l}\text { 힝 } \\
\text { 은 }\end{array}$ & 离 & 츤 \\
\hline$\sum_{i}$ & $\sum_{i}$ & 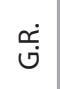 & $\stackrel{\leftrightarrow:}{N}$ & 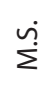 & $\overrightarrow{3}$ & $\sum_{\Sigma}^{\dot{v}}$ & $\sum_{\mathrm{N}}$ & ذ̇ & ن̀ & 递 & $\stackrel{\circ}{i}$ & 足 & $\dot{N}$ & $\stackrel{\leftrightarrow}{\circ}$ \\
\hline$\simeq$ & $\Sigma$ & $\Sigma$ & 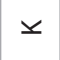 & $\Sigma$ & $\Sigma$ & $\Sigma$ & $\Sigma$ & $\Sigma$ & $\Sigma$ & $\Sigma$ & $\Sigma$ & $\Sigma$ & 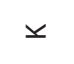 & $\check{x}$ \\
\hline$\stackrel{\circ}{\circ}$ & 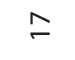 & $\stackrel{\infty}{-}$ & $\stackrel{9}{-}$ & $\stackrel{2}{N}$ & $\bar{N}$ & $\approx$ & $\stackrel{\dddot{v}}{\sim}$ & $\stackrel{d}{\sim}$ & $\stackrel{\Perp}{\sim}$ & $\stackrel{\sim}{N}$ & $\hat{\curvearrowright}$ & $\stackrel{\infty}{\sim}$ & શิ & $\stackrel{\circ}{\circ}$ \\
\hline
\end{tabular}




\section{RYCINA ( 1}

A. Wyznaczenie punktów odniesienia (kąciki oka) na zdjęciu. B. Wyodrębnienie obszaru pomiaru naczyń (Rol). C. Obszar występowania naczyń w ROI (maska). D. Monochromatyczny obraz maski.

A

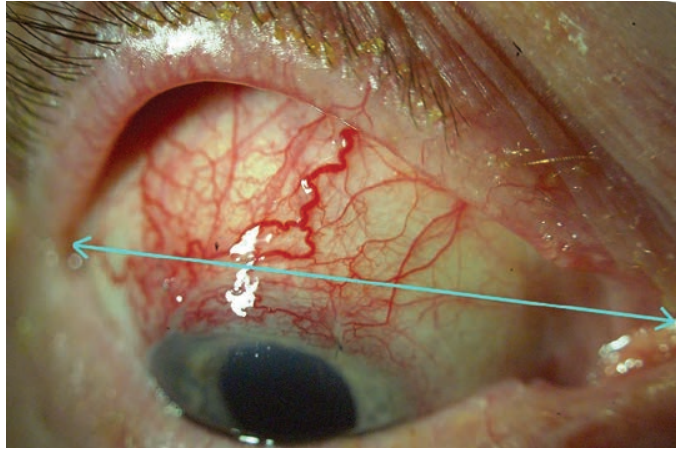

B

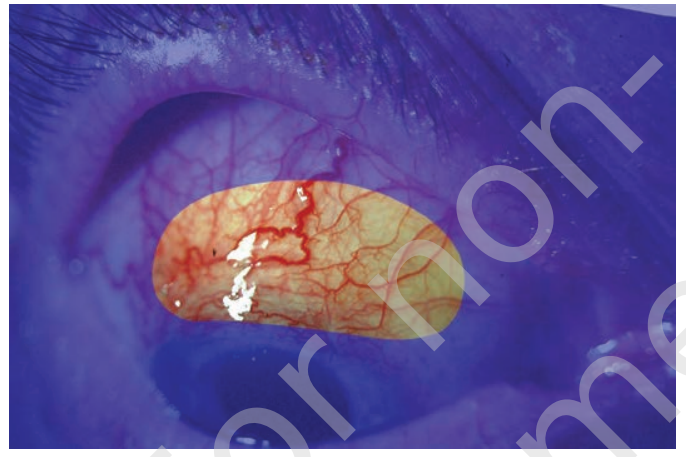

C

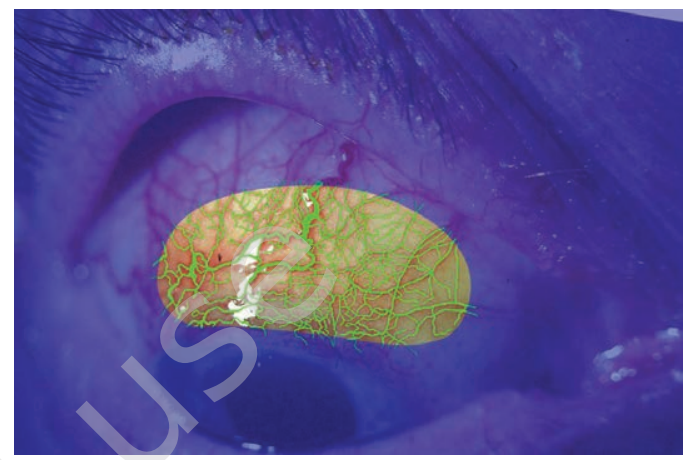

D

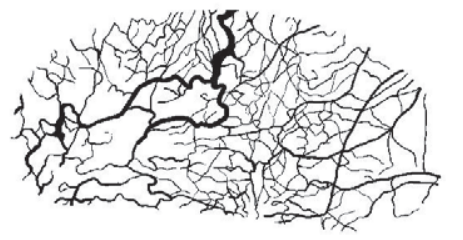

Zapisane maski wczytywano do programu ImageJ. Używając polecenia: Edycja $\rightarrow$ Selection $\rightarrow$ Create selection, tworzono selekcje dla poszczególnych masek (tj. uzyskiwano zaznaczenie obszaru pomiaru naczyń), a następnie za pomocą polecenia: Analyze $\rightarrow$ Measure, obliczano powierzchnię danej selekcji. Powierzchnia ROI stanowiła punkt odniesienia (100\%) dla pozostałych pomiarów. Wyniki pomiarów zapisywano $\mathrm{w}$ pliku indywidualnym dla każdego pacjenta tworzonym przez ImageJ (Results.xls). Korzystając z programu LibreOffice, obliczano za pomocą prostej formuły procentowy udział powierzchni naczyń do powierzchni ROI.

\section{WYNIKI}

\section{Ciśnienie wewnątrzgałkowe}

Średni procent obniżenia CWG wynosił 42,36 $\pm 24,03 \%$. 30-procentowe obniżenie CWG uzyskano u 20 osób, co stanowi $66,6 \%$ pacjentów poddanych analizie. Końcowe CWG w przedziale < 18 mmHg uzyskano u 25 osób, co stanowi $83,3 \%$ całej grupy poddanej analizie (ryc. 2).

\section{Powierzchnia naczyń pęcherzyka}

Po 2 tygodniach od rozpoczęcia stosowania bewacyzumabu uzyskano zmniejszenie średniej powierzchni naczyń pęcherzyka w porównaniu z okresem po zabiegu, przed rozpoczęciem stosowania bewacyzumabu. Była to różnica istotna statystycznie ( $\mathrm{p}=0,00002)$, a także największy odnotowany spadek powierzchni naczyń w całym badaniu. Po 2 miesiącach doszło również do zmniejszenia powierzchni naczyń pęcherzyka i w porównaniu z okresem po 2 tygodniach była to różnica istotna statystycznie. Po 6 miesiącach także odnotowano zmniejszenie powierzchni naczyń pęcherzyka i w porównaniu z okresem po 2 miesiącach była to różnica istotna statystycznie.

Po sprawdzeniu wszystkich zależności parametrów skali MBGS i powierzchni naczyń na poszczególnych etapach badania uzyskano dwie zależności istotne statystycznie: pomiędzy powierzchnią naczyń a unaczynieniem (V) po 2 i 6 miesiącach obserwacji.

Pełnym sukcesem operacji przeciwjaskrowej określono uzyskanie CWG końcowego < $18 \mathrm{mmHg}$ i jednocześnie obniżenie CWG wyjściowego o $30 \%$ bez stosowania leków przeciwjaskrowych po 6 miesiącach od operacji. Pełny sukces osiągnięto u 18 pacjentów, co stanowi 60\% chorych biorących udział w badaniu poddanych pełnej analizie. Częściowym sukcesem określono obniżenie CWG wyjściowego o $30 \%$ bez stosowania leków przeciwjaskrowych po 6 miesiącach od operacji. U 19 pacjentów osiągnięto częściowy sukces, co stanowi 63,3\% chorych uczestniczących w badaniu i poddanych pełnej analizie. 


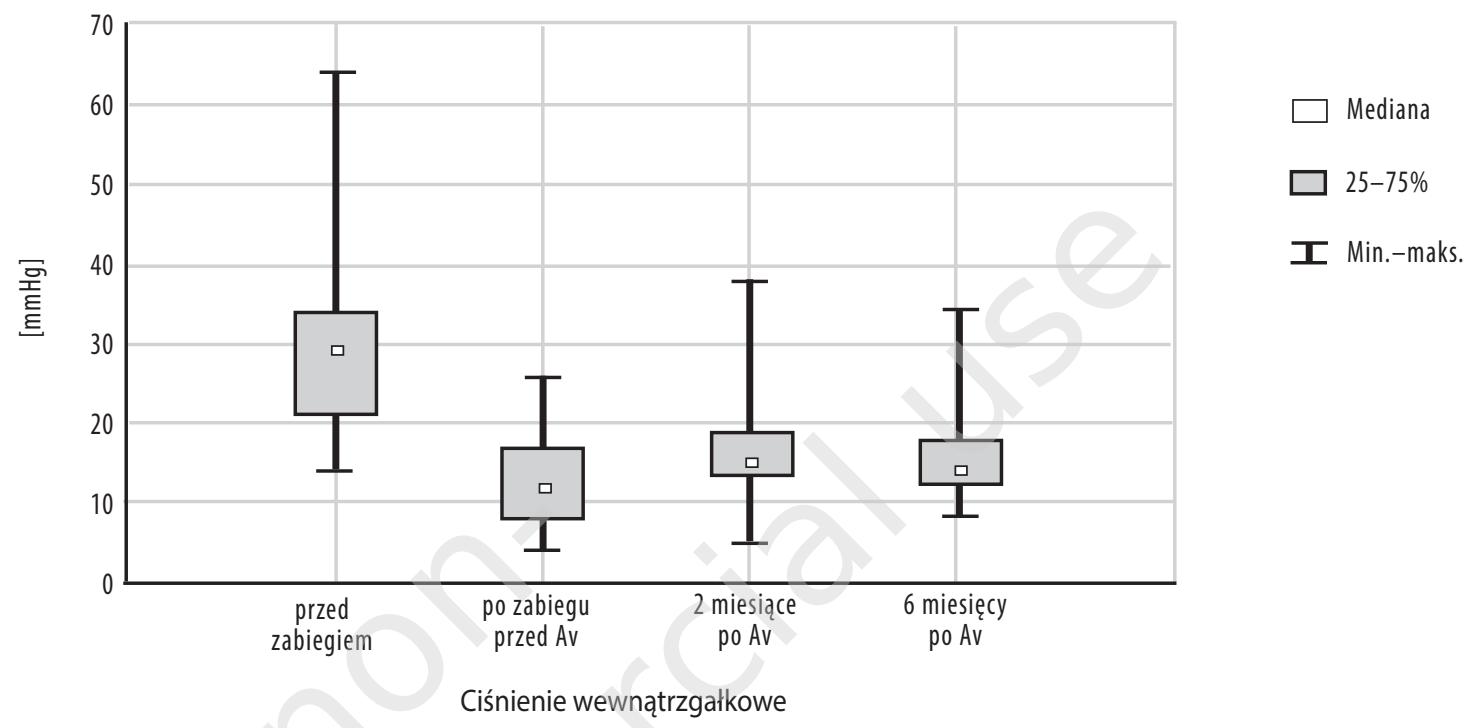

\section{OMÓWIENIE WYNIKÓW}

Wygląd i funkcja pęcherzyka filtracyjnego w początkowym okresie po operacji trabekulektomii ukierunkowują lekarza na wybór kolejnych metod leczenia. Zdjęcia fotograficzne wydają się w tym bardzo pomocne. Pozwalają ocenić tempo zblednięcia pęcherzyka po zastosowaniu bewacyzumabu w kroplach i ułatwiają konsultacje specjalistów z różnych ośrodków. Ocena zdjęć dobrze koreluje ze skalą MBGS, potwierdza jej słuszność, jednak dyskretne różnice w wyglądzie pęcherzyka można dostrzec na poszczególnych fotografiach i indywidualnie je określać. Nawet najlepiej wykonane zdjęcia nie zastąpią badania pacjenta w lampie szczelinowej z pomiarem CWG, oceną głębokości komory przedniej, oceną morfologiczną pęcherzyka i oceną jego szczelności.

Po raz pierwszy klasyfikacja pęcherzyka pod względem morfologii została opisana w 1949 r. przez Kronfelda. Obejmowała ona trzy typy pęcherzyka, skupiając się na jego wyglądzie i funkcji. Typem I według Kronfelda określano pęcherzyk cystoidalny, typ II to pęcherzyk prawidłowo filtrujący, typ III - pęcherzyk płaski, niefiltrujący [8]. Van Buskirk szczegółowo opisywał wygląd i funkcjonalność niewydolnych, otorbionych pęcherzyków [9]. Istnieją jednak przypadki, kiedy wygląd pęcherzyka nie koreluje z jego funkcją. Zobrazowanie budowy pęcherzyka może pomóc lepiej poznać zależność pomiędzy strukturą morfologiczną a funkcją pęcherzyka, a także zrozumieć proces gojenia rany pooperacyjnej po trabekulektomii. Pavlin i wsp. jako pierwsi zademonstrowali wewnętrzną budowę pęcherzyka, wykorzystując badania ultrabiomikroskopowe (UBM) [10].
Badanie to wymaga jednak kontaktu głowicy UBM z gałką, co obniża wiarygodność dokładnej oceny wyglądu pęcherzyka.

Bardziej szczegółowe opisy różnic w morfologii przetoki filtracyjnej zostały opisane przez Yamamoto i wsp. Badacze ci bazowali na refleksyjności wnętrza pęcherzyka. Sklasyfikowali oni pęcherzyki jako:

- $\quad \mathrm{z}$ niską refleksyjnością (low reflective - typ L)

- $\mathrm{z}$ wysoką refleksyjnością (high reflective - typ $\mathrm{H}$ ), otorbione (encapsulated - typ E)

- płaskie (flattened - typ F).

Dobrą kontrolę CWG gwarantowały pęcherzyki typu L, podczas gdy typy $\mathrm{H}$, E lub F sprzyjały raczej słabej kontroli CWG Savini i wsp. użyli tomografu Stratus OCT (Carl Zeiss Meditec, Dublin, California, USA) do zobrazowania pęcherzyków filtracyjnych. Wzorując się na obrazach OCT (optical coherence tomography), sklasyfikowali pęcherzyki pod względem ich budowy:

- typ A - cienka ściana i pojedyncza, duża przestrzeń płynowa

- typ B - cienka ściana i wiele przestrzeni wypełnionych płynem

- typ C - wiele płaskich przestrzeni płynowych.

Stratus OCT ma ograniczony zasięg penetracji do $2 \mathrm{~mm}$ głębokości, dlatego głębsze struktury wewnątrz pęcherzyka, takie jak klapka twardówki, nie mogą podlegać ocenie [11]. Badacze z Hongkongu podjęli próbę oceny morfologii pęcherzyków po trabekulektomii za pomocą modelu 
Visante OCT (ZEISS Visante OCT Model 1000, Carl Zeiss Meditec, Dublin, California, USA) służącego do obrazowania przedniego odcinka oka [12]. Główną przewagą Visante anterior segment OCT nad Stratus OCT jest głębsza penetracja tkanek (6 mm - Visante, $2 \mathrm{~mm}$ - Stratus), co jest zasługą wyższej częstotliwości diody użytej do obrazowania (1310 nm - Visante, $820 \mathrm{~nm}$ - Stratus) i pozwala uwidocznić głębsze struktury wewnątrz pęcherzyka. Metoda ta jest użyteczna do śledzenia ewolucji wewnętrznej budowy pęcherzyka, ukazuje aktywny proces remodelingu tkanek we wczesnym okresie po operacji, co pomaga określić różne typy pęcherzyka. Badanie to nie służy ocenie unaczynienia pęcherzyka lub określeniu testu Seidla, które to parametry można łatwo ocenić w lampie szczelinowej czy na fotografii pęcherzyka. Crowston i wsp. opracowali skalę oceny pęcherzyków dla użytku do telemedycznego badania $[13,14]$. Stanowiła ona podwaliny do wprowadzenia nowszego systemu oceny pęcherzyka opisanego przez Wellsa i wsp. [15]. Był on tworzony na podstawie badania 36 oczu w lampie szczelinowej oraz ocenie zdjęć fotograficznych. Poszczególne parametry (unaczynienie, grubość ściany, powierzchnia) były oceniane w skali od 1 do 10. Najbardziej wiarygodna okazała się ocena naczyń pęcherzyka. Zgodność w ocenie grubości i wyglądu ściany nie była jednoznaczna. Wykluczono ocenę testu Seidla na zdjęciach fotograficznych. Zdjęcia stereo były bardziej wiarygodne niż mono, jednak koszt aparatu i wyspecjalizowanych programów zdaje się niepraktyczny na dużą skalę. W naszym badaniu większość pęcherzyków miała powierzchnię centralną 25-50\%, powierzchnię maksymalną 25-50\%. Głównie były to pęcherzyki niezbyt wysokie, rozlane, unaczynione podobnie do otaczającej spojówki i lekko przekrwione.

Bezpieczeństwo bewacyzumabu potwierdza badanie $\mathrm{z}$ naszej kliniki, w którym porównywano skuteczność i bezpieczeństwo 5-FU i bewacyzumabu do wspomagania trabekulektomii [6]. Pomimo braku różnic statystycznych w końcowym efekcie trabekulektomii wykazano, iż bewacyzumab nie wpływa na śródbłonek, więc jest bezpieczniejszy od antymetabolitów.

Kolejne badanie dowodzi, że chociaż podspojówkowe iniekcje bewacyzumabu są efektywne i bezpieczne, to jednak po miejscowym zastosowaniu $0,2 \mathrm{mg} / \mathrm{ml} \mathrm{MMC}$ na 3 min obserwowano lepszą kontrolę CWG. Końcowe CWG $<12$ mmHg uzyskano w 33\% oczu z bewacyzumabem i w 71\% z MMC, bez stosowania leków przeciwjaskrowych pooperacyjnie [16]. Podobne wyniki uzyskano u 34 pacjentów na 36 oczach poddanych trabekulektomii. Niższe wartości CWG po średnio 8 miesiącach obserwowano $\mathrm{u}$ chorych po zastosowaniu MMC bez leków przeciwjaskrowych niż w grupie z bewacyzumabem z 0,2 \pm 0,5 leków przeciwjaskrowych [17]. Wielu badaczy opisywało działanie bewacyzumabu jako środka wspomagającego operacje przetokowe w jaskrze [18, 19]. Po jednorazowej iniekcji 1,25 mg bewacyzumabu podspojówkowo po operacji trabekulektomii w 6-miesięcznej obserwacji średni spadek CWG wynosił 52\%. Poziom ciśnienia po tym okresie zawierał się w granicach $8-14 \mathrm{mmHg}$ bez konieczności stosowania leków przeciwjaskrowych u 92\% pacjentów [20]. Podczas obserwacji naszych pacjentów obniżenie CWG o $30 \%$ po 6 miesiącach w porównaniu do ciśnienia wyjściowego uzyskano u 66,6\% pacjentów. Wśród chorych, u których nie uzyskano 30\% obniżenia, CWG < $18 \mathrm{mmHg}$ nie stwierdzono u pięciu pacjentów, z czego u trzech osób nie przekraczało $21 \mathrm{mmHg}$.

Biorąc pod uwagę ogólnoustrojowe i miejscowe bezpieczeństwo, użycie bewacyzumabu w okulistyce jest bardzo zachęcające. Niewielu badaczy opisywało poważne ogólne objawy uboczne po takim zastosowaniu leku. Krótka obserwacja pacjentów w naszym badaniu wykazała prawidłowo funkcjonujące pęcherzyki i redukcję CWG po pooperacyjnym użyciu kropli bewacyzumabu. Brak oznak lokalnej toksyczności leku na spojówkę, zapaleń wewnątrzgałkowych czy objawów ogólnych u badanych pacjentów wskazuje na kliniczne bezpieczeństwo i tolerancję.

Wśród pacjentów biorących udział w niniejszym badaniu 27 osób stosowało bewacyzumab w kroplach nie dłużej niż 30 dni. Nie stwierdzono zależności istotnej statystycznie pomiędzy zmniejszeniem powierzchni naczyń pęcherzyka a czasem stosowania bewacyzumabu. Zalecanym standardowym postępowaniem po operacjach przeciwjaskrowych jest stosowanie miejscowych glikokortykosteroidów (GKS) co $2 \mathrm{~h}$ przez pierwsze 2 tygodnie po zabiegu, zmniejszając do 4 razy dziennie przez kolejne 6 tygodni, a następnie redukując stopniowo dawkę w ciągu 3 miesięcy [21]. GKS działają przeciwzapalnie i mają pozytywny wpływ na prawidłowe uformowanie pęcherzyka filtracyjnego [22]. Opisywano również zalecenia co do pooperacyjnego stosowania GKS przez 6 do 8 tygodni, jednak lepiej dla pęcherzyka jest stosować je do 3 miesięcy po operacji [23]. Spaeth i wsp. dowiedli, że w oczach leczonych miejscowymi glikokortykosteroidami CWG było znacząco niższe niż $\mathrm{w}$ nieleczonych, co potwierdzili również inni autorzy [24, 25]. Zastosowanie GKS przez krótszy okres po operacji może doprowadzić do spadku efektywności trabekulektomii.

W przypadku niewydolności pęcherzyka filtracyjnego stosowanie miejscowych GKS jest zwykle niewystarczające, dlatego podejmowane są próby stosowania preparatów anty-VEGF. Wydaje się, że zastosowanie pooperacyjnie kropli bewacyzumabu jest obiecujące [26]. Stanowi terapię pomocniczą dla GKS, jest wygodne, krople wpuszczane są w warunkach domowych, podawanie jest nieinwazyjne dla pacjenta. Wadą stosowania bewacyzumabu w kroplach jest cena preparatu i częstotliwość wpuszczania kropli - 5 razy dziennie. Dla porównania podspojówkowa iniekcja 5-FU 
może stanowić trudność dla pacjenta związaną z logistyką, gdyż w tym przypadku koniecznością jest podanie leku w szpitalu. Stosowanie antymetabolitów wiąże się z występowaniem powikłań, a mianowicie mogą pojawić się nieszczelność rany spojówki, punktowate erozje, filamenty, owrzodzenia jałowe i bakteryjne oraz rogowacenie rogówki, krwotok nadnaczyniówkowy, zapalenie wnętrza gałki ocznej i makulopatia.

Wadą naszego badania jest mała grupa pacjentów, krótki okres obserwacji oraz brak grupy kontrolnej dla pełnego wykazania skuteczności i bezpieczeństwa stosowania bewacyzumabu. Stwarza to trudności w określeniu znaczących wniosków. Wyłaniają się trzy metody stosowania bewacyzumabu: przedoperacyjnie, śródoperacyjnie oraz pooperacyjnie. Niniejsze badanie wykazuje, że pooperacyjne stosowanie kropli bewacyzumabu jest sensowne i poprawia wygląd pęcherzyka filtracyjnego, szczególnie dzięki zmniejszeniu jego unaczynienia we wczesnym okresie pooperacyjnym. Zastosowanie śródoperacyjne w postaci iniekcji podspojówkowych ma podobny wpływ na końcowy efekt trabekulektomii jak użycie antymetabolitów [6]. Przewagą jest jednak brak toksycznego wpływu na rogówkę. Zastosowanie przedoperacyjne bewacyzumabu jest niemniej obiecujące. Barierę stanowi krótki okres półtrwania leku (1,4 dnia), co zmuszałoby do kontynuacji leczenia podczas i po zabiegu. Nie wiemy jednak, jaki będzie efekt ostateczny po użyciu przedoperacyjnym bewacyzumabu. Porównanie skuteczności metody zastosowania bewacyzumabu jest trudne. Konieczne są dalsze badania i długie obserwacje.

\author{
ADRES DO KORESPONDENCJI \\ dr n. med. Anna Kuna \\ Klinika Diagnostyki i Mikrochirurgii Jaskry, \\ Uniwersytet Medyczny w Lublinie \\ 20-079 Lublin, ul. Chmielna 1 \\ tel./faks +48 815326149 \\ e-mail: ryan84@onet.eu
}

\section{PODSUMOWANIE}

Zastosowanie pooperacyjne kropli bewacyzumabu stanowi skuteczną terapię pomocniczą dla miejscowych GKS w celu leczenia wczesnej pooperacyjnej niewydolności pęcherzyka filtracyjnego poprzez zmniejszenie unaczynienia pęcherzyka.

Krople bewacyzumabu są całkowicie bezpiecznym rozwiązaniem leczenia wczesnej pooperacyjnej niewydolności pęcherzyka filtracyjnego.

Ocena powierzchni naczyń pęcherzyka na zdjęciu fotograficznym koreluje z oceną pęcherzyka w skali MBGS.

Wczesna pooperacyjna niewydolność pęcherzyka definiowana jest jako pęcherzyk, którego powierzchnia naczyń przekracza $20 \%$ jego całego obszaru.

Źródto rycin: Wszystkie ryciny pochodzq z materiałów własnych autora/autorów.

Projekt pracy zostat zaakceptowany przez Komisje Bioetyczna przy Uniwersytecie Medycznym w Lublinie (nr decyzji KE-0254/166/2012).

The study design was approved by the Bioethics Committee of the Medical University of Lublin (no. KE-0254/166/2012).

\section{ORCID}

Anna Kuna - ID - http://orcid.org/0000-0003-2083-3707

Tomasz Żarnowski - ID - http://orcid.org/0000-0002-6978-7417

\section{Piśmiennictwo}

1. Cairns JE. Trabeculectomy. Preliminary report of a new method. Am J Ophthalmol. 1968; 66: 673-8.

2. Ferrara N. Role of vascular endothelial growth factor in regulation of angiogenesis. Kidney Int. 1999; 56: 794-814.

3. Senger DR, Galli SJ, Dvorak AM et al. Tumor cells secrete a vascular permeability factor that promotes accumulation of ascites fluid. Science (Wash DC). 1983; 219: 983-5.

4. Hurwitz H, Fehrenbacher L, Novotny W et al. Bevacizumab plus irinotecan, fluorouracil, and leukovorin for metastatic colorectal cancer. New Engl. J. Med. 2004; 350: 2335-42.

5. Kitazawa Y, Kawase K, Matsushita H et al. Trabeculectomy with mitomycin. A comparative study with fluorouracil. Arch Ophthalmol. 1991; 109(12): 1693-8.

6. Jurkowska-Dudzińska J, Kosior-Jarecka E, Żarnowski T. Comparison of the use of 5-FU and bevacizumab in primary trabeculectomy: results at one year. Clin Exp Ophthalmol. 2012; 40: 135-42. 
7. Kłos-Rola J, Tulidowicz-Bielak M, Żarnowski T. Effects of topical bevacizumab application on early bleb failure after trabeculectomy: observational case series. Clin Ophthalmol. 2013; 7: 1929-35.

8. Kronfeld PC. The mechanism of filtering operations. Trans Pac Coast Otoophthalmol Soc Annu Meet. 1949; 33: 23-40.

9. Van Buskirk EM. Cysts of Tenon's capsule following filtration surgery. Am J Ophthalmol. 1982; 94: 522-7.

10. Pavlin CJ, Harasiewicz K, Foster FS. Ultrasound biomicroscopy of anterior segment structures in normal and glaucomatous eyes. Am J Ophthalmol. 1992; 113(4): 381-9.

11. Savini G, Zanini M, Barboni P. Filtering blebs imaging by optical coherence tomography. Clin Exp Ophthalmol. 2005; 33: 483-9.

12. Leung CK, Yick DW, Kwong YY et al. Analysis of bleb morphology after trabeculectomy with Visante anterior segment optical coherence tomography. Br J Ophthalmol. 2007; 91(3): 340-4.

13. Crowston JG, Kirwan JF, Wells AP et al. Evaluating clinical signs in trabeculectomized eyes. Eye. 2004; 18: $299-303$.

14. Crowston JG, Wells AP, Kirwan J et al. Distant evaluation of postoperative trabeculectomy cases. Clin Experiment Ophthalmol. 2000; suppl: 134.

15. Wells AP, Crowston JG, Marks J et al. A pilot study of a system for grading of drainage blebs after glaucoma surgery. J Glaucoma. 2004; 13(6): 454-60.

16. Akkan JU, Cilsim S. Role of subconjunctival bevacizumab as an adjuvant to primary trabeculectomy: a prospective randomized comparative 1-year follow-up study. J Glaucoma. 2015; 24(1): 1-8.

17. Nilforushan N, Yadgari M, Kish SK et al. Subconjunctival bevacizumab versus mitomycin C adjunctive to trabeculectomy. Am J Ophthalmol. 2012; 153(2): 352-7.

18. Ichhpujani P, Ramasubramanian A, Kaushik S et al. Bevacizumab in glaucoma: a review. Can J Ophthalmol. 2007; 42: 812-515.

19. Miki A, Ochima Y, Otori $Y$ et al. Efficacy of intravitreal bevacizumab as adjunctive treatment with pars plana vitrectomy, endolaser photocoagulation, and trabeculectomy for neovascular glaucoma. Br J Ophthalmol. 2008; 92: 1431-3.

20. Grewal DS, Jain R, Kumar $\mathrm{H}$ et al. Evaluation of subconjunctival bevacizumab as an adjunct to trabeculectomy: a pilot study. Ophthalmology. 2008; 115: 2141-5.

21. Spaeth GL. Chirurgia okulistyczna. Elsevier Urban \& Partner, Wrocław 2006.

22. Fuller JR, Bevin TH, Molteno ACB et al. Anti-inflammatory fibrosis suppression in threatened trabeculectomy bleb failure produces good long term control of intraocular pressure without risk of sight threatening complications. Br J Ophthalmol. 2002; 86(12): 1352-4.

23. Arosemena A, Ayyala RS. Steps for saving failing blebs after trabeculectomy. Needling can be successful in early and late cases of bleb revision. Ocular Surgery News. U.S. Edition, February 1, 2004.

24. Fechner PU, Wichman W. Retarded corneo-scleral wound healing associated with high preoperative doses of systemic steroids in glaucoma surgery. Refract Corneal Surg. 1991; 7: 174-6.

25. Roth SM, Spaeth GL, Starita RJ et al. The effects of postoperative corticosteroids on trabeculectomy and the clinical course of glaucoma: Five year follow-up study. Ophthalmic Surg. 1991; 22: 724-9.

26. Żarnowski T, Tulidowicz-Bielak M. Topical bevacizumab is efficacious in the early bleb failure after trabeculectomy. Acta Ophthalmol. 2011; 89: 605-6.

Wkład autorów:

Anna Kuna: zebranie danych do badania (kwalifikacja i pełne badanie pacjentów na każdej wizycie), wykonanie fotografii pęcherzyka filtracyjnego i obróbka materiału, przygotowanie i opracowanie analizy statystycznej, napisanie pracy; Tomasz Żarnowski: koncepcja badania i jego projekt, zoperowanie większości pacjentów biorących udział w badaniu, konsultacje pacjentów na kolejnych wizytach, pomoc w przygotowaniu i napisaniu pracy.

Konflikt interesów:

Nie występuje.

Finansowanie:

Nie występuje.

Etyka:

Treści przedstawione w artykule są zgodne z zasadami Deklaracji Helsińskiej, dyrektywami EU oraz ujednoliconymi wymaganiami dla czasopism biomedycznych.
Authors' contributions:

Anna Kuna: collecting the data (qualification and full examination of patients), photos of the filtering bubble and full processing of the material, preparing statistical analysis, writing; Tomasz Żarnowski: concept of the study, treatment of the majority of patients participating in the study, patient consultations at subsequent visits, assistance in the preparation and writing of a thesis.

Conflict of interest:

None.

Financial support:

None.

Ethics:

The content presented in the article complies with the principles of the Helsinki

Declaration, EU directives and harmonized requirements for biomedical journals. 